\title{
An RNAi-based screen reveals PLK1, CDK1 and NDC80 as potential therapeutic targets in malignant pleural mesothelioma
}

\author{
A Linton ${ }^{1,4}$, Y Y Cheng ${ }^{1,4}$, K Griggs ${ }^{2}$, M B Kirschner ${ }^{1}$, S Gattani ${ }^{1}$, S Srikaran ${ }^{1}$, S Chuan-Hao Kao ${ }^{1}$, \\ B C McCaughan ${ }^{3}$, S Klebe ${ }^{2}$, N van Zandwijk ${ }^{1}$ and G Reid ${ }^{*}, 1$ \\ ${ }^{1}$ Asbestos Diseases Research Institute (ADRI), University of Sydney, Concord, NSW 2139, Australia; ${ }^{2}$ Department of Anatomical \\ Pathology, Flinders Medical Centre, Bedford, SA, Australia and ${ }^{3}$ Cardiothoracic Surgical Unit, Royal Prince Alfred Hospital; The \\ Baird Institute and Sydney Medical School, University of Sydney, Sydney, Australia
}

Background: Malignant pleural mesothelioma (MPM) is an aggressive tumour originating in the thoracic mesothelium. Prognosis remains poor with 9- to 12-month median survival, and new targets for treatments are desperately needed.

Methods: Utilising an RNA interference (RNAi)-based screen of 40 genes overexpressed in tumours, including genes involved in the control of cell cycle, DNA replication and repair, we investigated potential therapeutic targets for MPM. Following in vitro characterisation of the effects of target silencing on MPM cells, candidates were assessed in tumour samples from 154 patients.

Results: Gene knockdown in MPM cell lines identified growth inhibition following knockdown of NDC80, CDK1 and PLK1. Target knockdown induced cell-cycle arrest and increased apoptosis. Using small-molecule inhibitors specific for these three proteins also led to growth inhibition of MPM cell lines, and Roscovitine (inhibitor of CDK1) sensitised cells to cisplatin. Protein expression was also measured in tumour samples, with markedly variable levels of CDK1 and PLK1 noted. PLK1 expression in over $10 \%$ of cells correlated significantly with a poor prognosis.

Conclusion: These results suggest that RNAi-based screening has utility in identifying new targets for MPM, and that inhibition of NDC80, CDK1 and PLK1 may hold promise for treatment of this disease.

Malignant pleural mesothelioma (MPM) is a malignant tumour of the serosal membrane lining the thoracic cavity that remains very difficult to treat and is almost invariably fatal. Elicited by inhalation of asbestos fibres, the disease usually appears after a latency of several decades following first exposure (Lanphear and Buncher, 1992). Despite a ban on the use of asbestos in many developed countries, the incidence of MPM continues to rise, and predictions are that it will continue to do so until the middle of this century, largely due to the continued presence of asbestos in buildings (Linton et al, 2012).

The treatment options for MPM include surgery, radiotherapy and chemotherapy, with the actual therapy chosen dependent on factors such as performance status, extent of disease and tumour histopathology. Chemotherapy is the treatment of choice in unresectable disease, but single-agent treatment response rates are no more than $20 \%$. Even the currently used first-line therapeutic regimen of pemetrexed with cisplatin achieves a response in only $40 \%$ of patients, and provides an increase in median survival from 9 to 12 months (Vogelzang et al, 2003). New therapeutic targets are urgently needed, necessitating a better understanding of MPM biology.

A number of reports of gene expression profiling in MPM have been published, but the results have been variable with little overlap in the genes identified (Singhal et al, 2003; Pass et al, 2004;

\footnotetext{
*Correspondence: Dr G Reid; E-mail: glen.reid@sydney.edu.au

${ }^{4}$ These authors contributed equally to this work.
}

Received 3 September 2013; revised 14 October 2013; accepted 25 October 2013; published online 10 December 2013 
Lopez-Rios et al, 2006; Romagnoli et al, 2009). The studies have also varied in their aims, with prognostic and predictive markers targeted in several cases. Nevertheless, some investigators have attempted to identify potential therapeutic targets (Singhal et al, 2003; Romagnoli et al, 2009); identified genes were involved in glucose metabolism (Singhal et al, 2003), cytoskeleton remodelling (Singhal et al, 2003), cell cycle (Pass et al, 2004; Lopez-Rios et al, 2006; Romagnoli et al, 2009) and signalling (Pass et al, 2004; Lopez-Rios et al, 2006). Most recently, an extensive survey of the differences between gene expression in parietal and visceral pleural membranes and MPM was reported. The authors identified a number of overexpressed genes which they postulated may represent potential therapeutic targets. These genes included those involved in DNA replication and repair and control of the cell cycle (Roe et al, 2010). Many are also implicated in the intrinsic chemoresistance of MPM tumours. Similarly, a report focusing specifically on the expression of cell-cycle genes found a number of these to be overexpressed in MPM tumours and cell lines compared with controls (Romagnoli et al, 2009).

With the advent of RNA interference (RNAi) as a molecular tool, the suitability of specifically overexpressed genes as therapeutic targets can be rapidly assessed. However, this technique has only been used to investigate a few cases of MPM. CHEK1 was identified as overexpressed in MPM, and silencing its expression in MPM lines led to increased apoptosis and sensitisation to doxorubicin (Romagnoli et al, 2009). With the aim of identifying further genes that may serve as therapeutic targets in MPM, we have combined the results from previous gene expression studies with a rational RNAi-based screen to assess the effects of gene silencing on MPM cell growth. Silencing 40 genes involved in cell cycle and DNA replication and repair and previously reported to be overexpressed in MPM (Singhal et al, 2003; Pass et al, 2004; Lopez-Rios et al, 2006; Romagnoli et al, 2009), we identified NDC80, CDK1 and PLK1 as potential therapeutic targets for MPM.

\section{MATERIALS AND METHODS}

Chemicals and reagents. Chemicals and reagents, including RNase and propidium iodide (PI), were purchased from SigmaAldrich (Sigma, St Louis, MO, USA). SYBR Green I and TRIzol were purchased from Life Technologies (Carlsbad, CA, USA). The CDK1 inhibitor Roscovitine, PLK1 inhibitor BI 2536, and the CHEK1 inhibitor AZD7726 were purchased from Selleck (Houston, TX, USA). The NDC80 inhibitor, INH1, was from Tocris Bioscience (Minneapolis, MN, USA). Cisplatin was purchased from McFarlane Medical and Scientific (Sydney, Australia) and Gemcitabine was from Eli Lilly (Sydney, Australia).

Cell culture. The human MPM cell lines H28, H226, H2452 and MSTO-211H, and the transformed human mesothelial cell line MeT-5A, were purchased from the American Type Culture Collection (ATCC, Manassas, VA, USA). MM05 cells were provided by Kwun Fong and Raylene Bowman, The Prince Charles Hospital, Australia (Relan et al, 2013). Cell lines were maintained in RPMI medium supplemented with $10 \%$ heatinactivated fetal calf serum (FCS) except MeT-5A cells which were cultured in DMEM supplemented with 10\% FCS. Media and FCS were from Life Technologies.

siRNAs and transfection. All siRNAs and transfection reagents were purchased from Life Technologies. Two independent siRNAs specific for each target gene were used and sequences are listed in Supplementary Table 1. Lipofectamine RNAiMax (LRM) was used to introduce siRNAs into cells via reverse transfection. An LRM concentration of $0.8 \mu \mathrm{lml}^{-1}$ was used for transfections in all cell lines. Lipoplexes were transferred to multi-well tissue culture plates and overlaid with $5 \times 10^{3}$ cells per $\mathrm{cm}^{2}$ for ATCC lines and $10 \times 10^{3}$ cells per $\mathrm{cm}^{2}$ for the MM05 line. Following overnight incubation, the transfection medium was replaced.

Real-time PCR. Total RNA was isolated with TRIzol, and the concentration and purity were determined using a NanoPhotometer (Implen, Munich, Germany). Reverse transcription was performed with $100 \mathrm{ng}$ total RNA using the AffinityScript qPCR cDNA Synthesis Kit and oligo(dT) primers according to the manufacturer's instructions (Stratagene, Agilent Technologies, Santa Clara, CA, USA). Reactions were incubated in a PCR Thermocycler (Labnet International, Edison, NJ, USA) at $42^{\circ} \mathrm{C}$ for $5 \mathrm{~min}, 55^{\circ} \mathrm{C}$ for $15 \mathrm{~min}$ and $95^{\circ} \mathrm{C}$ for $5 \mathrm{~min}$. The resulting cDNA (10 ng) was amplified using $180 \mathrm{~nm}$ primers (Supplementary Table 1) and SYBR Green qPCR Master Mix (Stratagene). Realtime qPCR was performed on a Stratagene Mx3000P (Agilent Technologies). The cycling protocol consisted of an initial $10 \mathrm{~min}$ denaturation step at $95^{\circ} \mathrm{C}$ followed by 40 cycles of denaturation at $95^{\circ} \mathrm{C}$ for $15 \mathrm{~s}$ and annealing/extension at $55^{\circ} \mathrm{C}$ for $60 \mathrm{~s}$. mRNA expression levels were determined using the $2^{-\Delta \Delta \mathrm{Cq}}$ method (Livak and Schmittgen, 2001) with normalisation to GAPDH and expression calculated relative to the corresponding controltransfected cells.

Growth assays. To measure the effects on cell growth of siRNAmediated target gene knockdown or target-specific small-molecular inhibitors, an SYBR Green I-based fluorometric assay was used. Briefly, at the indicated time points following transfection or drug addition, plates were frozen at $-80^{\circ} \mathrm{C}$. At the completion of the assay, plates were thawed and $200 \mu \mathrm{l}$ cell lysis buffer $(10 \mathrm{~mm}$ Tris $\mathrm{HCl}$ pH 8.0 containing $2.5 \mathrm{~mm}$ EDTA, 1\% Triton X-100) containing SYBR Green I $(1: 4000 \mathrm{v} / \mathrm{v})$ were added to the wells. After overnight incubation in the dark at $4{ }^{\circ} \mathrm{C}$, cell lysates were mixed thoroughly, and DNA fluorescence was measured with a FluoStar Optima plate reader (BMG Labtech, Ortenberg, Germany) set at an excitation frequency of $485 \mathrm{~nm}$ and measuring emission at $535 \mathrm{~nm}$.

Colony formation assays. Cells (2500 cells per well) were transfected with $1 \mathrm{~nm}$ siRNA in 96-well plates. After $24 \mathrm{~h}$, cells were re-plated in 6-well plates and incubated for a further 10-14 days. Alternatively, cells were plated at low density in 6-well plates and $24 \mathrm{~h}$ later treated with target-specific small-molecule inhibitors. Following 10-14 day incubation, medium was removed and cells fixed in $70 \%$ ethanol, then stained in $10 \%$ ethanol solution containing $0.1 \%$ crystal violet for $1 \mathrm{~h}$. Following destaining, colonies were counted.

Annexin V and PI apoptosis and cell-cycle analysis. To assess apoptosis, cells were transfected with $5 \mathrm{~nm}$ siRNA specific for CDK1, NDC80, PLK1 (two siRNAs per target gene) or control in 6 -well plates at a density of $3 \times 10^{5}$ cells per well in RPMI containing 10\% FCS. After incubation for $48 \mathrm{~h}$, cells were harvested and washed three times with phosphate-buffered saline (PBS). Cells were either fixed with $70 \%$ ethanol for cell-cycle analysis or stained with the FITC Annexin V Apoptosis Detection Kit (Life Technologies) for Tali image-based apoptosis assay (Life Technologies). For detection of apoptosis, cells were incubated with Annexin V and PI for $20 \mathrm{~min}$ at room temperature in the dark. Annexin V and PI stained live cells were then loaded on a Tali Cellular Analysis Slide for Tali image-based apoptosis analysis. Cells stained with Annexin and/or PI were counted and each experiment was performed in triplicate.

For cell-cycle analysis, fixing solution was removed and cells were treated with $0.01 \%$ RNase $\left(10 \mathrm{mg} \mathrm{ml}^{-1}\right.$, Sigma), $0.05 \%$ PI in PBS for $30 \mathrm{~min}$ at $37^{\circ} \mathrm{C}$ in the dark. The cell-cycle distribution was determined on an Accuri C6 flow cytometer (BD Biosciences, Franklin Lakes, NJ, USA) within $30 \mathrm{~min}$. The flow cytometer was calibrated using 6- and 8-peak fluorescent bead mixtures provided by the manufacturer, and according to their instructions (Accuri, 
Ann Arbor, MI, USA). The flow cytometer was routinely operated at the Slow Flow Rate setting (14 $\mu$ l sample per minute), and data acquisition for a single sample typically occupied 3-5 min. For each sample, 10000 events were counted and cell cycle was analysed using the FlowJo software (Ashland, OR, USA). Each experiment was performed in triplicate.

Western blot anlaysis. To assess protein expression, cells were transfected with $5 \mathrm{~nm}$ siRNA specific for CDK1, NDC80, PLK1 (two siRNAs per target gene) or control (C81) in 6-well plates at a density of $2 \times 10^{5}$ cells per well. After incubation for $48 \mathrm{~h}$, cells were harvested for protein isolation. For western blot analysis, cell lysates were prepared with RIPA buffer (Pierce, Rockford, IL, USA) plus Complete protease inhibitors (Roche Diagnostics, Mannheim, Germany) according to the manufacturers' instructions. Protein concentration was determined by BCA assay (Pierce) and cell lysates $(20 \mu \mathrm{g}$ per lane) were separated on SDS-PAGE under reducing conditions before transfer onto nitrocellulose membrane using the Trans-Blot Turbo Transfer System (Bio-Rad, Hercules, CA, USA) and immunoblotted using anitbodies specific for PLK1 (Anti-PLK1-clone-35-206, 1:1000; Millipore, Billerica, MA, USA), NDC80 (ab3613, 1:1000; Abcam, Cambridge, MA, USA) and CDK1 (Anti-CDC2-9112; 1:1000; Cell Signalling, Boston, MA, USA). Immunoreactive proteins were detected using anti-mouse (for PLK1 and NDC80) and anti-rabbit (CDK1) horseradish peroxidase-conjugated secondary antibody and SuperSignal West Femto (all from Pierce). The membranes were stripped with Restore Western Blot Stripping Buffer (Pierce) and immunoblotted with a mouse monoclonal antibody against $\beta$-actin (Sigma, $1: 1000)$. Imaging was carried out using a Gel Logic 2200 Imaging System (Kodak, Rochester, NY, USA) under non-saturating conditions.

Patients and samples. Our retrospective cohort consisted of 154 consecutive patients, either with a confirmed pathological diagnosis of MPM who underwent extrapleural pneumonectomy (EPP) from 1994 to 2009 at Royal Prince Alfred and Strathfield Private Hospitals (Sydney, Australia) (Kao et al, 2011a, 2013) or pleurectomy and/or decortication (P/D) for whom pathological tissue was available between October 1991 and 2009 at Royal Prince Alfred Hospital. The details of the patients were kept in a prospectively collected database with additional demographic and survival data identified from hospital records. The histologic diagnosis and subtypes of MPM were determined in accordance with the World Health Organisation criteria. The study was approved by the Human Research Ethics Committees at the Sydney South West Area Health Service (Concord Repatriation General Hospital Zone) and the Human Research Ethics Committees of Flinders Medical Centre. Informed consent from all participants was obtained.

Tissue microarray construction. Haematoxylin and eosin slides from formalin-fixed paraffin-embedded (FFPE) tissue blocks were reviewed. Areas containing tumour were marked on the slides, and the corresponding areas then marked on the FFPE blocks. Utilising previously validated methods (Kao et al, 2011b), the Advanced Tissue Arrayer, ATA-100 (Millipore) was used to construct tissue microarrays (TMAs) consisting of a minimum of four cores of $1 \mathrm{~mm}$ from the donor blocks inserted into a recipient block. The recipient blocks were arranged in a systematic manner and $4-\mu \mathrm{m}$ sections of the TMAs were cut and applied to slides for later use.

Immunohistochemistry. Tissue microarray slides were deparaffinised and rehydrated before quenching with $10 \% \mathrm{H}_{2} \mathrm{O}_{2}$. The sections were incubated with anti-PLK1 (1:1200; Millipore) or anti-CDC2 (CDK1) mouse monoclonal antibody (Anti-CDC29116, 1:50; Cell Signalling). Positive controls were used during optimisation and final testing in accordance with the manufacturer's instructions (T-cell lymphoma [PLK1]/benign lymphoid tonsillar hyperplasia [CDC2]). The sections were detected with the NovoLink Polymer complex reagent (Leica Microsystems, Bannockburn, IL, USA). Immunolabelling was visualised with $\mathrm{DAB}+$ Substrate Chromogen System (Dako, VIC, Australia), followed by haematoxylin counter-staining. For quantitative evaluation, the percentage of labelled cells (from $0 \%$ to 100\%), irrespective of intensity, was assessed by a qualified anatomical pathologist (SK). The investigator was not aware of the survival data when scoring was assessed. An average was calculated from assessable cores with note taken of the site of the labelling.

Statistical analysis. Data were analysed using an unpaired $t$-test or repeated measures ANOVA followed by Fisher's protected least significant difference test using Statview 4.02 (Abacus Concepts, Inc., Berkeley, CA, USA). A $P$-value of $<0.05$ was considered as statistically significant. Overall survival (OS) was calculated from the date of diagnosis to the date of death or last follow-up, and was the primary end point of this study. Patients were censored at last follow-up if still alive or lost to follow-up. Univariate Cox models were evaluated for age, sex, histologic subtype, PLK1 and CDK1 score, and hazard ratios calculated. PLK1 and CDK1 expression was assessed both as variable level (at increments of $10 \%$ expression) and as categorical variable (using a cutoff value). In a preliminary assessment of PLK1 and CDK1 labelling, we found a median score of $3 \%$ and $16 \%$, respectively. For scoring to be both practical and clinically robust, scores of $<10 \%$ and $\geqslant 10 \%$ for PLK1 and $<20 \%$ and $\geqslant 20 \%$ for CDK1 were chosen. Variables with a $P$-value of $<0.05$ were considered as statistically significant and were examined by Kaplan-Meier curves. The univariate variables were then entered into a multivariate Cox model including age, sex and histologic subtype, as they are generally accepted prognostic factors. These analyses were performed using SPSS for Windows version 19.0 (SPSS, Inc., Chicago, IL, USA).

\section{RESULTS}

A rational RNAi-based screen identifies potential targets in MPM. On the basis of the results from previous gene expression profiling studies (Romagnoli et al, 2009; Roe et al, 2010) in MPM, we selected 40 targets for RNAi-mediated knockdown and designed 2 siRNAs per target gene (Supplementary Table 1). In the initial screen, all 40 targets were individually silenced by 2 independent siRNAs in the MPM lines H28 and MSTO-211H (Figure 1A). Targets for which both siRNAs resulted in greater than $50 \%$ (black boxes represent $>50 \%$ ) growth inhibition were BIRC5, CDK1, CHEK1, NDC80, PLK1, RRM1 and RRM2 (Figure 1A). The mRNA expression of each target following transfection was assessed in $\mathrm{H} 28$ cells to determine the efficacy of the siRNAs (Figure 1A). In general, similar results were obtained from each of the two siRNAs specific for independent sites in the target message.

As small-molecule inhibitors have been developed for CDK1, NDC80 and PLK1 and they have not previously been linked to MPM, these targets were considered further. Silencing of each gene resulted in time- and dose-dependent growth inhibition for 5 days post transfection (Figure 1B) and this correlated with reductions in mRNA and protein (Figure $1 \mathrm{~A}$ and D, respectively). Silencing CDK1 (1 nM) decreased cell growth by $20 \%$ (MM05) to $80 \%$ (MSTO-211H) 5 days post transfection. Similarly for NDC80 knockdown this was between 25\% (MM05) and 80\% (MSTO$211 \mathrm{H}$ ) and for PLK1 between 48\% (MM05, H28 and H2452) and $80 \%$ (MSTO-211H). In addition, silencing CDK1, NDC80 and PLK1 resulted in reduced clonogenic survival in colony formation assays when compared with control siRNA-transfected cells (Figure 1C). All growth inhibitory effects following siRNA 


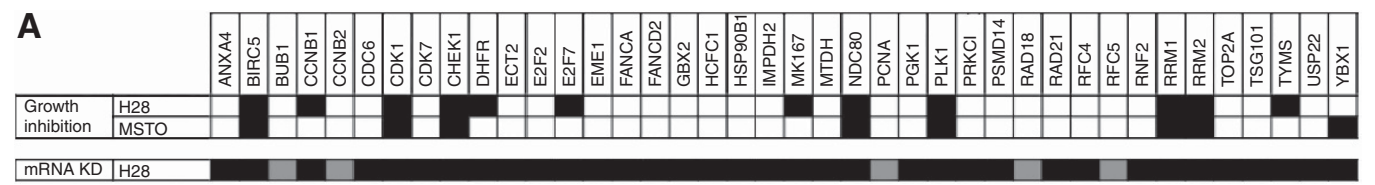

B
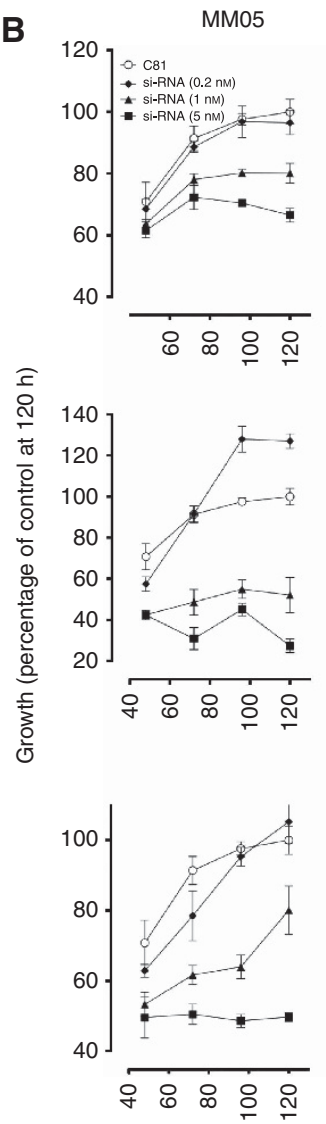

MSTO-211H
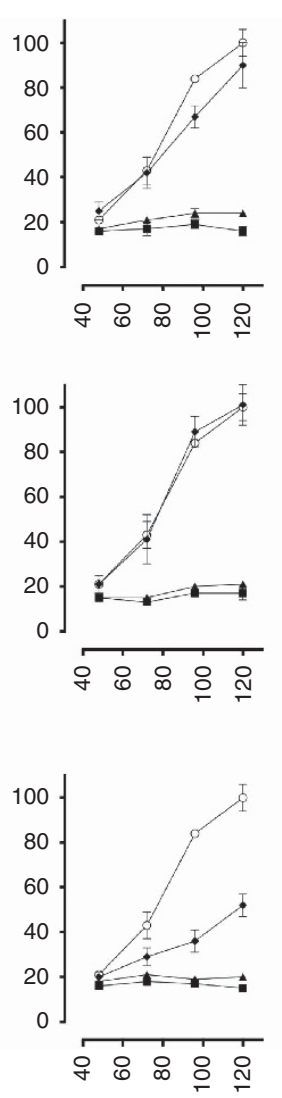

$\mathrm{H} 28$
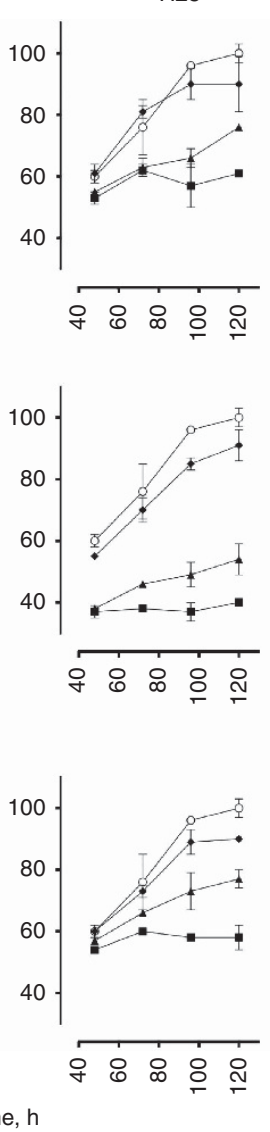

H2452
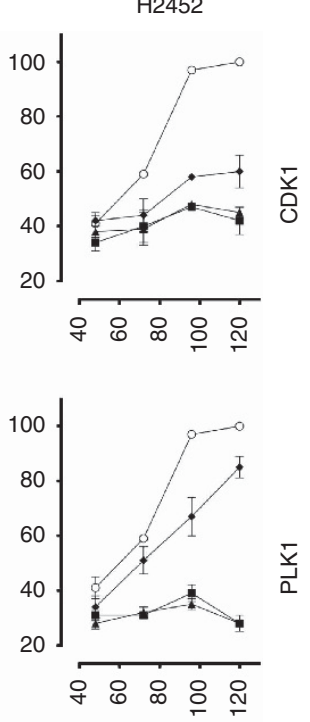

C

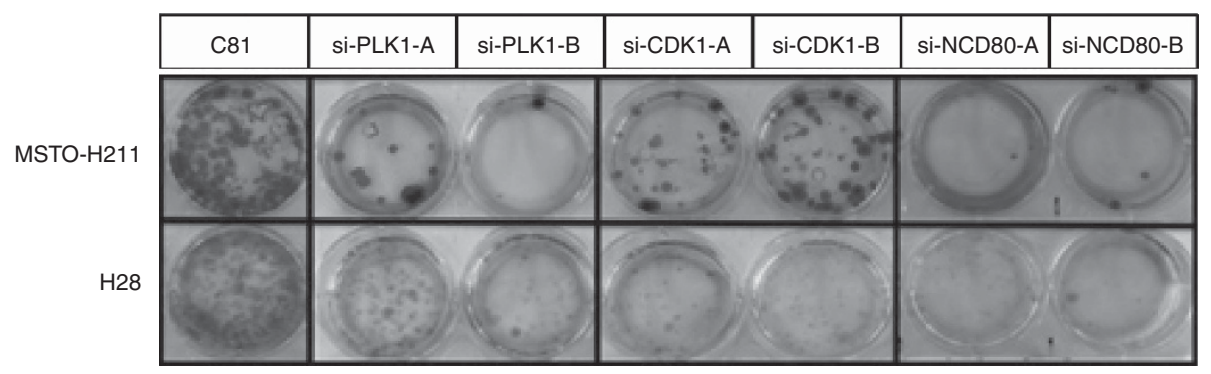

D
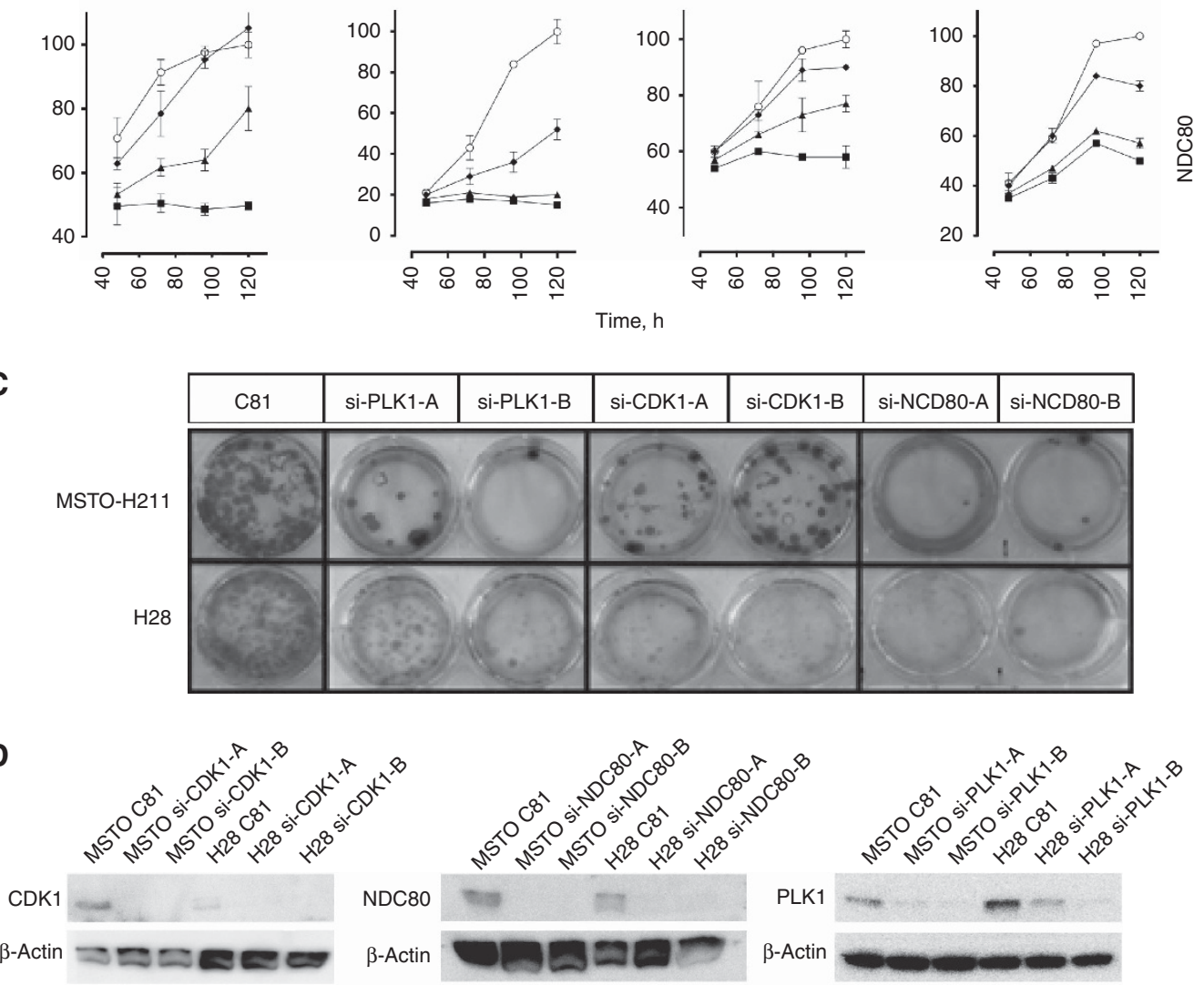

$\beta$-Actin $\mathrm{S}=\beta$-Actin

Figure 1. Rational RNAi screen identifies new targets in MPM. (A) Based on the previous reports, 40 genes were selected for knockdown screening. Growth inhibition was measured in four MPM cell lines. Black boxes represent $>50 \%$ inhibition with two independent siRNAs for specified target. mRNA expression following siRNA transfection was measured for each siRNA in $\mathrm{H} 28$ cells - black represents $>75 \%$ knockdown

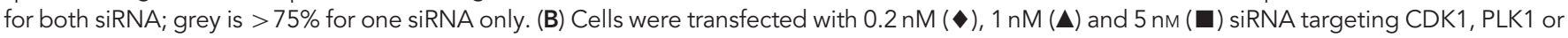
NDC80. Cells were harvested at the indicated times and the effect on cell growth measured. Data were compared with cells transfected with a control non-silencing siRNA [C81] (O). Values are expressed as mean \pm s.d. (C) Cells were transfected with $1 \mathrm{~nm}$ siRNA in 96-well plates, and $24 \mathrm{~h}$ later were transferred to 6-well plates. After incubation for a further 10-14 days, cell was fixed and stained with crystal violet. (D) Protein levels in MSTO-211 $\mathrm{H}$ and $\mathrm{H} 28$ cells treated with $1 \mathrm{~nm}$ siRNA were determined by western immunoblotting. Representative pictures are shown. $\beta$-Actin acted as a loading control. Similar results were obtained from all other cell lines (data not shown). 
transfection correlated with a strong and specific reduction in target protein expression (Figure 1D).

Analysis of cell cycle following knockdown revealed an increase in the percentage of cells in $\mathrm{G}_{2} / \mathrm{M}$ phase in both $\mathrm{H} 28$ and MSTO$211 \mathrm{H}$ cell lines with an accompanying decrease in the proportion of cells in $G_{0} / G_{1}$ (Figure $2 A$ ). Cells transfected with siRNA specific for CDK1 or PLK1 showed a two-fold increase in the G2/M population. The sub-G1 phase increased following knockdown of all three targets, although the effect was more pronounced in MSTO- $211 \mathrm{H}$ cells. Similar results were observed with MM05 cells (not shown). To determine whether mitotic arrest led to the induction of apoptosis, H28 and MSTO-211H cells were analysed for annexin V/PI binding following targeted silencing of CDK1, NDC80 and PLK1 (Figure 2B). Image-based cytometric analysis with Annexin $\mathrm{V}$ and PI staining showed an increase in the percentage of $\mathrm{H} 28$ and $\mathrm{MSTO}-211 \mathrm{H}$ cells undergoing early apoptosis following decreased expression of CDK1, NDC80 and PLK1 (Figure 2B). Induction of apoptosis was also evidenced by an increase in DNA fragmentation following CDK1, NDC80 and PLK1 silencing (Supplementary Figure 2).

Inhibitors of CDK1, NDC80 and PLK1 reduce the growth of MPM cells. Given the growth inhibitory effects of silencing the three candidate genes in MPM cells, we next tested small-molecule inhibitors of CDK1 (roscovitine), NDC80 (INH1) and PLK1
(BI 2536) in a panel of MPM cell lines. Treatment with the CDK1 inhibitor roscovitine and the NDC80 inhibitor INH1 inhibited the growth of all MPM cell lines with half-maximal inhibitory concentration $\left(\mathrm{IC}_{50}\right)$ ranging from 30 to $60 \mu \mathrm{M}$ and 25 to $90 \mu \mathrm{M}$, respectively. The small-molecule inhibitor of PLK1, BI 2536, was also cytotoxic in MPM cells, with $\mathrm{IC}_{50}$ values in the low $\mathrm{nM}$ range (Figure $3 \mathrm{~A})$. The three drugs also inhibited colony formation of MPM cells (data not shown).

Sensitising effects of roscovitine and INH1 on cisplatin toxicity in MPM cells. To test whether inhibition of PLK1, CDK1 or NDC80 was able to sensitise cells to clinically used drugs, H226 and MSTO- $211 \mathrm{H}$ cells were treated simultaneously with cisplatin in combination with BI 2536, roscovitine or INH1. Roscovitine $(33 \mu \mathrm{M})$ increased the cisplatin sensitivity of MSTO-211H cells by 3.3 -fold, and H226 cells by 2.5- to 4 -fold (Figure 3B). We observed a modest two-fold sensitisation when MSTO-211H cells were treated with cisplatin in the presence of INH1 $(12.2 \mu \mathrm{M})$, but there was no effect of INH1 on the sensitivity of H226 cells to cisplatin (Figure 3B). BI 2536 had no effect on cisplatin toxicity in either MPM line (data not shown). Furthermore, neither roscovitine, INH1 nor BI 2536 was able to influence gemcitabine toxicity in MPM cell lines (data not shown). In contrast, the CHEK1 inhibitor AZD $7726(20 \mu \mathrm{M})$ sensitised both lines by $\sim 2$-fold (Supplementary Figure 1).
A
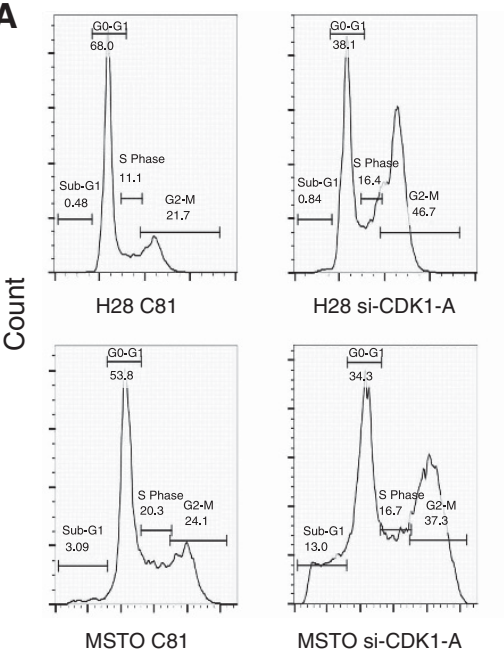

H28 si-CDK1-A

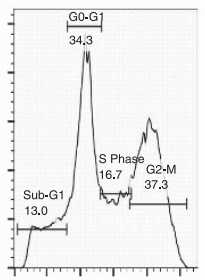

MSTO si-CDK1-A

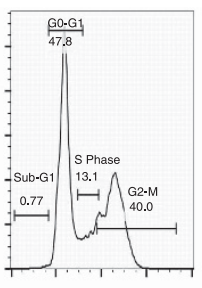

H28 si-CDK1-B

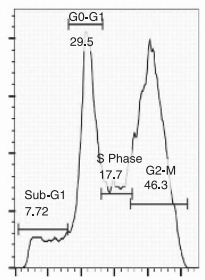

MSTO si-CDK1-B

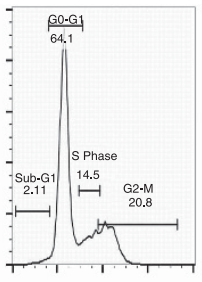

H28 si-NDC80-A

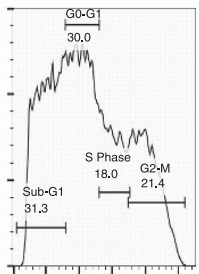

MSTO si-NDC80-A FL2-A

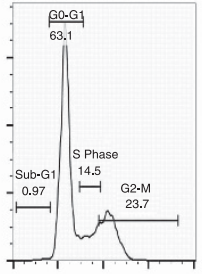

H28 si-NDC80-B

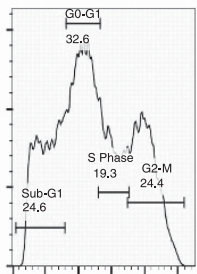

MSTO si-NDC80-B

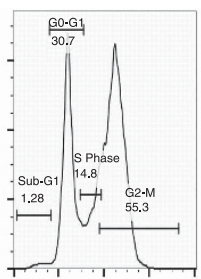

H28 si-PLK1-A

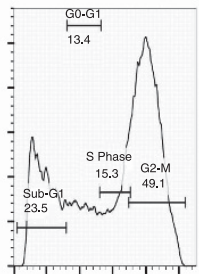

MSTO si-PLK1-A

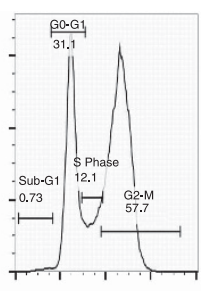

H28 si-PLK1-B

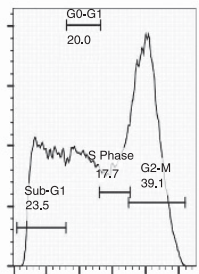

MSTO si-PLK1-B
B

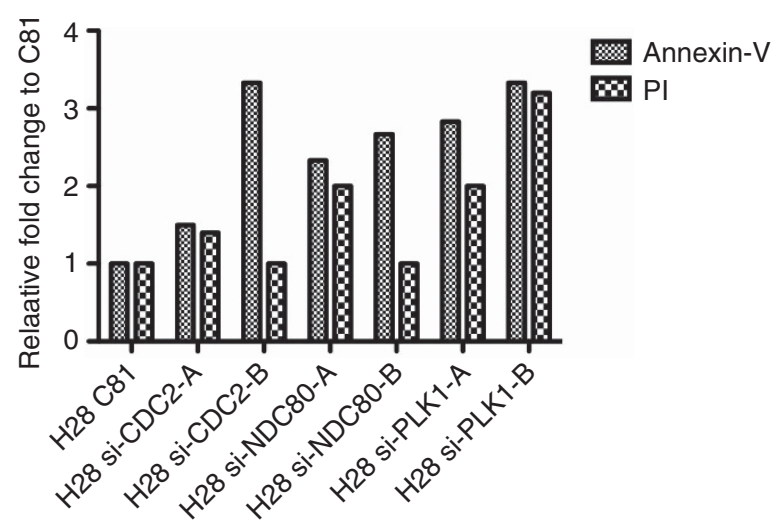

MSTO Annexin-V and PI staining

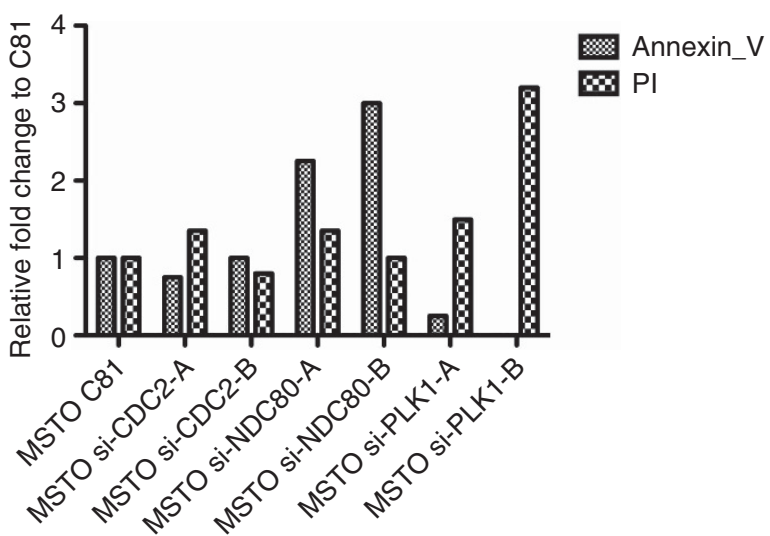

Figure 2. Target gene knockdown induces cell-cycle arrest and apoptosis in MPM cells. (A) MPM cells were transfected with control siRNA or gene-specific siRNA (5 nm) and changes in cell-cycle progression were analysed by Accuri C6 flow cytometry $48 \mathrm{~h}$ post transfection. Representative histograms are shown. (B) MPM cells transfected with the same siRNA as in (A) were harvested $48 \mathrm{~h}$ post transfection and the induction of apoptosis was assessed by Annexin $\mathrm{V}$ and $\mathrm{PI}$ staining using the Tali image-based flow cytometry system. 

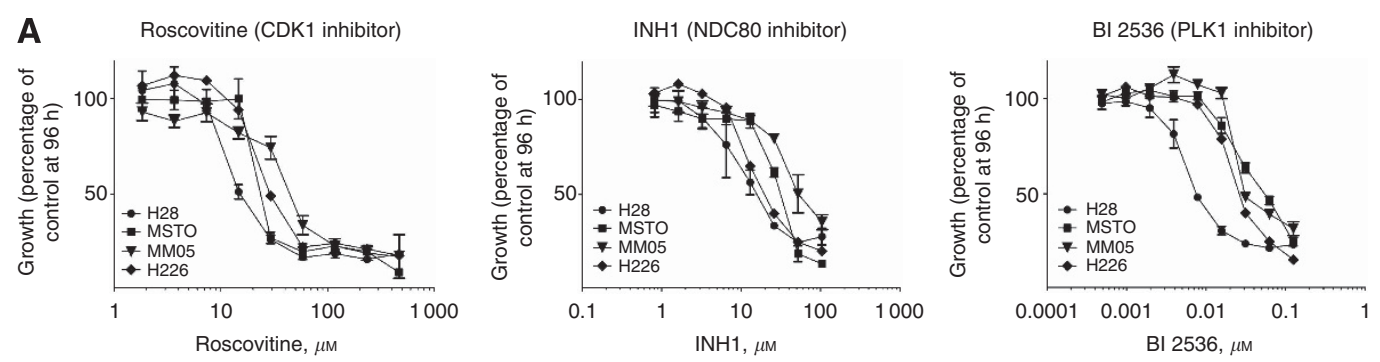

B
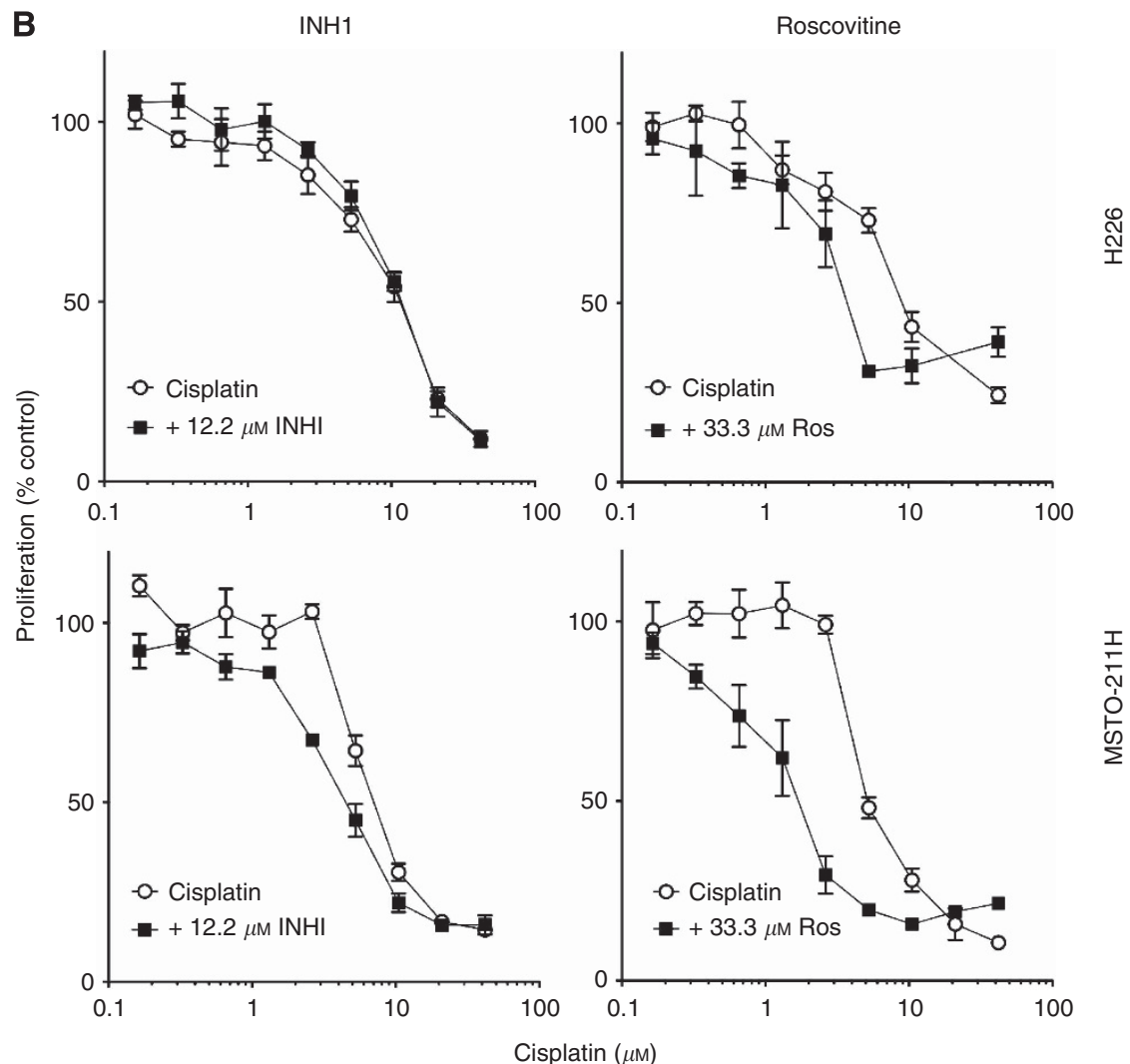

Figure 3. Roscovitine sensitises MPM cells to cisplatin. (A) MPM cell lines were treated with increasing concentrations of Roscovitine, INH1 or BI 2536 and cytotoxic effects were determined at $96 \mathrm{~h}$. (B) MPM cell lines were treated with increasing concentrations of cisplatin together with the indicated concentration of Roscovitine and INH1 and cytotoxic effects were determined at $96 \mathrm{~h}$.

PLK1 and CDK1 are expressed in tumour samples with PLK1 representing an independent prognostic marker in MPM. To determine the clinical relevance of the targets identified in the RNAi screen, we assessed expression in two patient series. The first series consisted of 80 patients who underwent EPP between 1994 and 2004, with the second comprising 74 patients who underwent P/D between 1991 and 2009 (Supplementary Table 2 summarises the baseline characteristics for the combined cohorts). The median OS was 14.2 months, with $90 \%$ of patients deceased at the time of analysis $(n=138)$. The expression of candidates for which antibodies were available was assessed in the TMAs. Immunohistochemistry (IHC) demonstrated nuclear staining of PLK1, while nuclear and cytoplasmic staining was noted for CDK1 (Figure 4A). The median PLK1 expression averaged across assessable cores was $3.05 \%$ (range $0-42.5 \%$; $12 \%$ of patients PLK1 expression over $10 \%$ ) and median CDK1 expression was 16.0\% (range 0.5-96\%). Upon assessment of OS, a statistically significant reduction was noted at PLK1 expression of $>10 \%$ (15.5 vs 5.0 months; $P=0.004$, see Figure $4 \mathrm{~B}$ and Table 1). In contrast, the expression of CDK1 did not correlate with survival. Younger age, epithelioid histological subtype and female gender conferred a significant survival advantage.
Univariate analysis, using PLK1 as a continuous variable and a categorical variable at a cutoff value of $10 \%$, revealed a statistically significant decline in prognosis at higher PLK1 expression (Table 2A). CDK1 did not demonstrate a significant prognostic value. Upon multivariate analysis, including known prognostic factors, PLK1 expression remained a statistically significant biomarker (Table 2B).

\section{DISCUSSION}

Despite a modest improvement in survival observed after the introduction of pemetrexed/cisplatin for systemic treatment, the prognosis of MPM patients has remained poor. Alternatives for the treatment of MPM patients are clearly needed, and in this study we have used an RNAi-based approach to identify novel therapeutic targets. We used previously published data (Singhal et al, 2003; Pass et al, 2004; Lopez-Rios et al, 2006; Romagnoli et al, 2009; Roe et al, 2010; Relan et al, 2013) to select 40 genes overexpressed in MPM, and found that knockdown of BIRC5, 

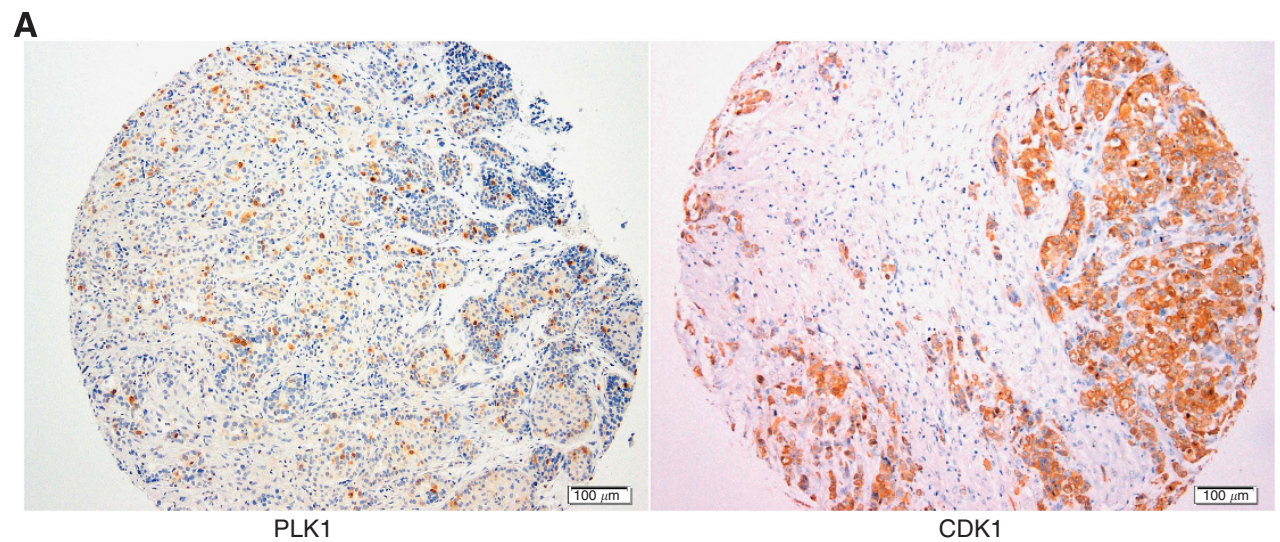

B
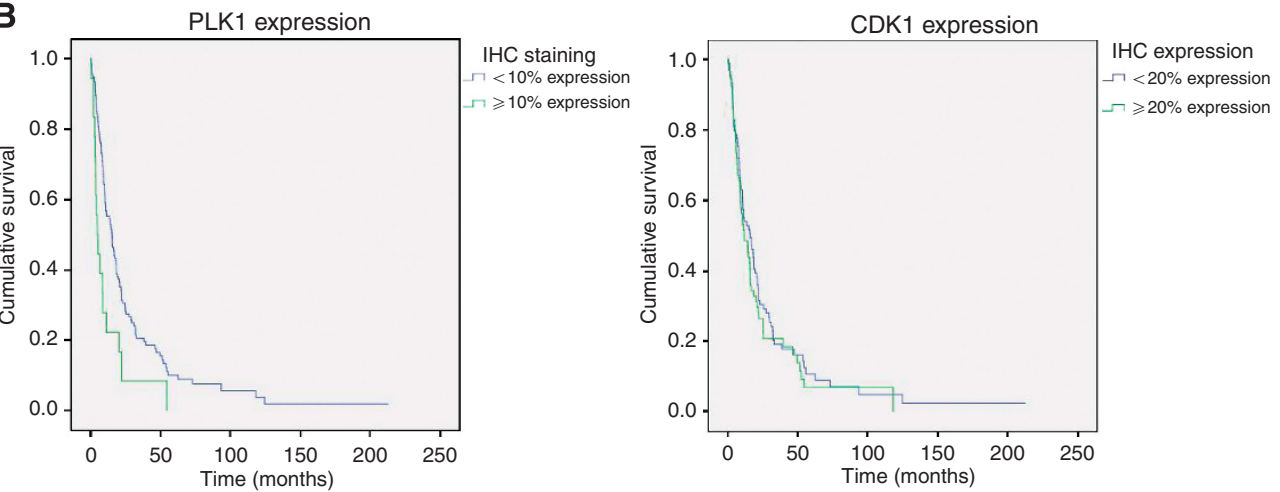

Figure 4. Prognostic value of PLK1 and CDK1 expression in MPM tumours. Representative immunohistochemical staining of pleural tissue in patients diagnosed with malignant pleural mesothelioma with PLK1 and CDK1 antibodies. (A) Nuclear staining for PLK1 (left) and nuclear and cytoplasmic staining for CDK1 following IHC testing of MPM tumour tissue. (B) Overall survival from diagnosis according to immunohistochemical expression of PLK1 and CDK1.

\begin{tabular}{|c|c|c|c|}
\hline Age & $\begin{array}{c}<60 \text { years } v s \geqslant 60 \\
\text { years }\end{array}$ & $\begin{array}{l}18.2 \text { vs } 9.6 \\
\text { months }\end{array}$ & $P=0.001$ \\
\hline $\begin{array}{l}\text { Histological } \\
\text { subtype }\end{array}$ & $\begin{array}{l}\text { Epithelioid vs } \\
\text { non-epithelioid }\end{array}$ & $\begin{array}{c}18.7 \text { vs } 7.7 \\
\text { months }\end{array}$ & $P<0.001$ \\
\hline Gender & Male vs female & $\begin{array}{c}11.5 \text { vs } 21.9 \\
\text { months }\end{array}$ & $P=0.007$ \\
\hline $\begin{array}{l}\text { PLK1 } \\
\text { expression }\end{array}$ & $<10 \%$ vs $\geqslant 10 \%$ & $\begin{array}{l}15.5 \text { vs } 5.0 \\
\text { months }\end{array}$ & $P=0.004$ \\
\hline $\begin{array}{l}\text { CDK1 } \\
\text { expression }\end{array}$ & $<20 \%$ vs $\geqslant 20 \%$ & $\begin{array}{c}15.7 \text { vs } 11.5 \\
\text { months }\end{array}$ & $P=0.388$ \\
\hline
\end{tabular}

CDK1, CHEK1, NDC80, PLK1, RRM1 and RRM2 led to growth inhibition in a panel of MPM cell lines, in line with the wellcharacterised roles of these genes in cancer biology. Nevertheless, an involvement in MPM cell growth and survival has previously been demonstrated only for PLK1 (Kawata et al, 2011). Interestingly, a number of genes previously reported to inhibit growth when silenced in other cancers-CCNB1 (Androic et al, 2008), PSMD14 (Byrne et al, 2010) and RAD18 (Wong et al, 2012)-had no effect on proliferation when silenced in the MPM cell lines in our study. Taken together, these observations support the use of RNAi-based screens to identify molecular targets in MPM.

In further characterisation of candidate therapeutic targets we focused on PLK1, CDK1 and NDC80/HEC1, as small-molecule inhibitors for these proteins have been developed. PLK1, a serine/ threonine kinase expressed predominantly in the late G2 and M phases of cell division, is responsible for the separation and maturation of the centrosome with a key role in regulating mitotic entry and exit (Lane and Nigg, 1996; Nigg, 1998). Overexpression of PLK1 has been associated with poor prognosis in NSCLC (Wolf et al, 1997), colorectal carcinoma (Han et al, 2012), breast carcinoma (King et al, 2012) and melanoma (Kneisel et al, 2002). Our findings suggest that the prognostic value of PLK1 expression extends also to MPM. Only a small proportion of patients demonstrated positive tumour staining for PLK1 with a median expression of $3 \%$ in our cohort. This is comparable to IHC data in breast cancer patients, where $11 \%$ demonstrated positive staining for PLK1 (King et al, 2012). In both tumour types, lower or nil PLK1 expression was associated with a significant and independent survival advantage.

The PLK1 inhibitor BI 2536 has been investigated in preclinical and clinical models, with in vitro activity in melanoma (de Oliveira et al, 2012), medulloblastoma (Harris et al, 2012) and breast cancer (Hu et al, 2012), consistent with our findings in MPM. As a result, BI 2536 has been assessed alone or in combination with other drugs in a number of phase I (Ellis et al, 2013) (Hofheinz et al, 2010; Frost et al, 2012) or single-agent phase II (Pandha et al, 2008; Sebastian et al, 2010) studies, with the predominant finding being disease stabilisation in $30-50 \%$ of patients. While PLK1 may serve as a biomarker to monitor treatment efficacy of small-molecule inhibitors such as BI 2536, it is uncertain whether the degree of overexpression offers predictive value in patients. Given the clear presence of a small but prognostically significant subset of MPM patients with markedly elevated levels of PLK1 expression within their tumours, it may prove worthwhile to assess the predictive role of baseline tumour expression in future studies of such inhibitors. 
Table 2. (A) and (B) Univariate and multivariate analyses of PLK1, CDK1 expression and known prognostic factors in MPM

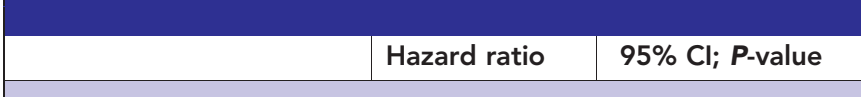

\begin{tabular}{|l|c|l|}
\hline \multicolumn{2}{|l|}{ (A) Univariate Analysis } \\
\hline $\begin{array}{l}\text { PLK1 (as a continuous } \\
\text { variable/10\% increments) }\end{array}$ & 1.88 & $1.32-2.68 ; P=0.001$ \\
\hline $\begin{array}{l}\text { PLK1 expression of } \geqslant 10 \% \\
\text { (vs }<10 \%)\end{array}$ & 2.09 & $1.25-3.50 ; P=0.005$ \\
\hline $\begin{array}{l}\text { CDK1 (as a continuous } \\
\text { variable/10\% increments) }\end{array}$ & 1.01 & $0.93-1.09 ; P=0.861$ \\
\hline $\begin{array}{l}\text { Non-epithelioid histology } \\
\text { (vs epithelioid) }\end{array}$ & 2.67 & $1.87-3.81 ; P<0.001$ \\
\hline $\begin{array}{l}\text { Age (variable/10-year } \\
\text { increase) }\end{array}$ & 1.39 & $1.17-1.65 ; P<0.001$ \\
\hline Gender-male (vs female) & 1.84 & $1.18-2.87 ; P=0.007$ \\
\hline
\end{tabular}

(B) Multivariate Analysis

\begin{tabular}{|l|c|c|}
\hline $\begin{array}{l}\text { PLK1 (as a continuous } \\
\text { variable/10\% increments) }\end{array}$ & 1.90 & $1.28-2.80 ; P=0.001$ \\
\hline $\begin{array}{l}\text { PLK1 expression of } \geqslant 10 \% \\
\text { (vs }<10 \%)^{a}\end{array}$ & 2.05 & $1.21-3.46 ; P=0.007$ \\
\hline $\begin{array}{l}\text { Non-epithelioid histology } \\
\text { (vs epithelioid) }\end{array}$ & 2.39 & $1.65-3.46 ; P<0.001$ \\
\hline $\begin{array}{l}\text { Age (variable/10-year } \\
\text { increase) }\end{array}$ & 1.22 & $1.01-1.48 ; P=0.042$ \\
\hline Gender-male (vs female) & 1.47 & $0.90-2.38 ; P=0.120$ \\
\hline
\end{tabular}

${ }^{a_{P L K} 1}$ as a continuous variable and as a categorical variable was analysed separately in the multivariate model with the other variables.

CDK1 (also known at Cell Division Control 2 [CDC2]) is a serine/threonine kinase that interacts with cyclin B1 to form an active heterodimer, driving progression from G2-M phase, and assisting in the regulation of mitosis (Castedo et al, 2002). CDK1 also has a clear influence upon apoptosis, with uncontrolled activation resulting in premature mitosis (and subsequent cell death), while also stimulating apoptotic pathways via the $\mathrm{Bcl}-2$ proteins. Overexpression of CDK1 has been associated with more aggressive disease, tumour infiltration and shorter survival in breast carcinoma (Chae et al, 2011), colon cancer (Meyer et al, 2009), hepatocellular carcinomas (Ito et al, 2000) and mantle cell lymphoma (Hui et al, 2005). Although expression of CDK1 was found in the majority of our MPM samples, it had no prognostic value. This may reflect the complexity of CDK1 function and its interplay with other cell-dependent kinases and cell-cycle regulatory proteins, thus limiting the prognostic value of determining the expression level of a single CDK. This was demonstrated in an analysis of 284 patients with breast cancer: high CDK1-specific activity was associated with a significant reduction in relapse-free survival (Kim et al, 2008), but combination with CDK2-specific activity (ratio CDK2/CDK1) led to greater prognostic accuracy.

Roscovitine, a small-molecule inhibitor of several CDKs including $\mathrm{CDK} 1 /$ cyclin $\mathrm{B}$, has inhibited tumour proliferation and promoted apoptosis both alone and in combination with other drugs in pre-clinical models (Mgbonyebi et al, 1998; Abaza et al, 2008; Appleyard et al, 2009). In phase I studies, roscovitine has been associated with modest efficacy. Of 56 patients with solid organ malignancies treated with roscovitine, 1 had partial response with 6 others achieving stable disease lasting for over 4 months (Le Tourneau et al, 2010). Phase II studies of roscovitine by Cyclacel have been carried out in NSCLC patients but have yet to be published.
The NDC80 complex connects chromosomal centromeres to mitotic spindle microtubules and consists of a rod-like assembly of four proteins, HEC1, Nuf20, SPC24P and SPC25. HEC1 in particular has a role in a number of processes including a mitotic control for kinetochore assembly, chromatic segregation, spindle organisation and biogenesis, and cell division. NDC80 mRNA levels were significantly increased in benign breast tumours in comparison with normal breast tissue, suggesting that NDC80 mRNA levels could serve as a marker of lesions that may be likely to undergo malignant transformation (Bieche et al, 2011). This finding is reinforced in mouse models where HEC1 overexpression was associated with a significant increase in lung adenomas and hepatic tumours (Diaz-Rodriguez et al, 2008). Our attempts to characterise the expression of NDC80/HEC1 in MPM tumour samples proved difficult due to the lack of NDC80 antibodies for IHC.

Inhibition of HEC1 via RNAi was associated with a reduction in xenograft tumour growth (Gurzov and Izquierdo, 2006; Li et al, 2007) prompting the investigation of INH1, a small-molecule inhibitor. INH1 has been demonstrated to disrupt the HEC1/NEK2 interaction, leading to a reduction in tumour proliferation in breast cancer, cervical adenocarcinoma and colon carcinoma cell lines. Furthermore, this compound also inhibited growth of breast cancer xenografts (Wu et al, 2008). As with PLK1 and CDK1, on the basis of our results following knockdown for NDC80 and use of INH1, we recommend further investigation on the role of this agent in MPM.

In addition to their involvement in proliferation, a role for PLK1 and CDK1 in chemotherapy resistance has been suggested. In breast cancer, targeting PLK1 with antisense oligonucleotides gave synergistic effects in combination with paclitaxel in cell lines and xenograft models (Spankuch et al, 2006), whereas squamous cell carcinoma cells transfected with PLK1-specific siRNA had enhanced sensitivity to cisplatin (Tyagi et al, 2010). Similarly, ectopic expression of miR-100 (a regulator of PLK1) and PLK1 knockdown were each associated with resensitisation of lung adenocarcinoma cells previously resistant to docetaxel (Feng et al, 2012). These findings reinforce breast carcinoma data where the usage of BI 2536 improved chemotherapy results in resistant cell populations ( $\mathrm{Hu}$ et al, 2012). However, we did not observe any effect of BI 2536 on the toxicity of cisplatin or gemcitabine in MPM cell cultures, suggesting a different role of PLK1 in MPM. Additional preclinical studies are required to provide a rationale for the use of anti-PLK1 therapy in chemotherapy-resistant patients or in combination with current chemotherapy.

In conclusion, we have demonstrated the applicability of RNAi screening to uncover new treatment targets for MPM. Our screen identified PLK1, CDK1 and NDC80 as novel targets with clear roles in MPM cell growth. Small-molecule inhibitors of these targets were growth inhibitory in MPM cell lines, and CDK1 and NDC80 inhibition also sensitised MPM cells to cisplatin. Furthermore, we have identified PLK1 expression as an independent prognostic factor. The need for new treatment approaches for MPM is clear. Given our promising findings, and the synergistic effects of small-molecule inhibitors of PLK1, CDK1 and NDC80 in combination with chemotherapy in other malignancies, further evaluation of these approaches in xenograft models is warranted.

\section{ACKNOWLEDGEMENTS}

We thank our colleagues for helpful discussions and review of the manuscript. This work was supported by grants from the Dust Diseases Board of NSW (2009-1) and Cancer Australia (1031821), both to GR. AL is supported by a Fellowship from the Biaggio Signorelli Foundation. 


\section{CONFLICT OF INTEREST}

The authors declare no conflict of interest.

\section{REFERENCES}

Abaza MS, Bahman AM, Al-Attiyah RJ (2008) Roscovitine synergizes with conventional chemo-therapeutic drugs to induce efficient apoptosis of human colorectal cancer cells. World J Gastroenterol 14(33): 5162-5175.

Androic I, Kramer A, Yan R, Rodel F, Gatje R, Kaufmann M, Strebhardt K, Yuan J (2008) Targeting cyclin B1 inhibits proliferation and sensitizes breast cancer cells to taxol. BMC Cancer 8: 391.

Appleyard MV, O'Neill MA, Murray KE, Paulin FE, Bray SE, Kernohan NM, Levison DA, Lane DP, Thompson AM (2009) Seliciclib (CYC202, $\mathrm{R}$-roscovitine) enhances the antitumor effect of doxorubicin in vivo in a breast cancer xenograft model. Int J Cancer 124(2): 465-472.

Bieche I, Vacher S, Lallemand F, Tozlu-Kara S, Bennani H, Beuzelin M, Driouch K, Rouleau E, Lerebours F, Ripoche H, Cizeron-Clairac G, Spyratos F, Lidereau R (2011) Expression analysis of mitotic spindle checkpoint genes in breast carcinoma: role of NDC80/HEC1 in early breast tumorigenicity, and a two-gene signature for aneuploidy. Mol Cancer 10: 23 .

Byrne A, McLaren RP, Mason P, Chai L, Dufault MR, Huang Y, Liang B, Gans JD, Zhang M, Carter K, Gladysheva TB, Teicher BA, Biemann HP, Booker M, Goldberg MA, Klinger KW, Lillie J, Madden SL, Jiang Y (2010) Knockdown of human deubiquitinase PSMD14 induces cell cycle arrest and senescence. Exp Cell Res 316(2): 258-271.

Castedo M, Perfettini JL, Roumier T, Kroemer G (2002) Cyclin-dependent kinase-1: linking apoptosis to cell cycle and mitotic catastrophe. Cell Death Differ 9(12): 1287-1293.

Chae SW, Sohn JH, Kim DH, Choi YJ, Park YL, Kim K, Cho YH, Pyo JS, Kim JH (2011) Overexpressions of Cyclin B1, cdc2, p16 and p53 in human breast cancer: the clinicopathologic correlations and prognostic implications. Yonsei Med J 52(3): 445-453.

de Oliveira JC, Brassesco MS, Pezuk JA, Morales AG, Valera ET, Montaldi AP, Sakamoto-Hojo ET, Scrideli CA, Tone LG (2012) In vitro PLK1 inhibition by BI 2536 decreases proliferation and induces cell-cycle arrest in melanoma cells. J Drugs Dermatol 11(5): 587-592.

Diaz-Rodriguez E, Sotillo R, Schvartzman JM, Benezra R (2008) Hecl overexpression hyperactivates the mitotic checkpoint and induces tumor formation in vivo. Proc Natl Acad Sci USA 105(43): 16719-16724.

Ellis PM, Chu QS, Leighl N, Laurie SA, Fritsch H, Gaschler-Markefski B, Gyorffy S, Munzert G (2013) A phase I open-label dose-escalation study of intravenous BI 2536 together with pemetrexed in previously treated patients with non-small-cell lung cancer. Clin Lung Cancer 14(1): 19-27.

Feng B, Wang R, Chen LB (2012) MiR-100 resensitizes docetaxel-resistant human lung adenocarcinoma cells (SPC-A1) to docetaxel by targeting Plk1. Cancer Lett 317(2): 184-191.

Frost A, Mross K, Steinbild S, Hedbom S, Unger C, Kaiser R, Trommeshauser D, Munzert G (2012) Phase i study of the Plk1 inhibitor BI 2536 administered intravenously on three consecutive days in advanced solid tumours. Curr Oncol 19(1): e28-e35.

Gurzov EN, Izquierdo M (2006) RNA interference against Hec1 inhibits tumor growth in vivo. Gene Ther 13(1): 1-7.

Han DP, Zhu QL, Cui JT, Wang PX, Qu S, Cao QF, Zong YP, Feng B, Zheng MH, Lu AG (2012) Polo-like kinase 1 is overexpressed in colorectal cancer and participates in the migration and invasion of colorectal cancer cells. Med Sci Monit 18(6): BR237-BR246.

Harris PS, Venkataraman S, Alimova I, Birks DK, Donson AM, Knipstein J, Dubuc A, Taylor MD, Handler MH, Foreman NK, Vibhakar R (2012) Polo-like kinase 1 (PLK1) inhibition suppresses cell growth and enhances radiation sensitivity in medulloblastoma cells. BMC Cancer 12: 80 .

Hofheinz RD, Al-Batran SE, Hochhaus A, Jager E, Reichardt VL, Fritsch H, Trommeshauser D, Munzert G (2010) An open-label, phase I study of the polo-like kinase-1 inhibitor, BI 2536, in patients with advanced solid tumors. Clin Cancer Res 16(18): 4666-4674.

Hu K, Law JH, Fotovati A, Dunn SE (2012) Small interfering RNA library screen identified polo-like kinase-1 (PLK1) as a potential therapeutic target for breast cancer that uniquely eliminates tumor-initiating cells. Breast Cancer Res 14(1): R22.
Hui D, Reiman T, Hanson J, Linford R, Wong W, Belch A, Lai R (2005) Immunohistochemical detection of cdc2 is useful in predicting survival in patients with mantle cell lymphoma. Mod Pathol 18(9): 1223-1231.

Ito Y, Takeda T, Sakon M, Monden M, Tsujimoto M, Matsuura N (2000) Expression and prognostic role of cyclin-dependent kinase 1 (cdc2) in hepatocellular carcinoma. Oncology 59(1): 68-74.

Kao SC, Klebe S, Henderson DW, Reid G, Chatfield M, Armstrong NJ, Yan TD, Vardy J, Clarke S, van Zandwijk N, McCaughan B (2011a) Low calretinin expression and high neutrophil-to-lymphocyte ratio are poor prognostic factors in patients with malignant mesothelioma undergoing extrapleural pneumonectomy. J Thorac Oncol 6(11): 1923-1929.

Kao SC, Lee K, Armstrong NJ, Clarke S, Vardy J, van Zandwijk N, Reid G, Burn J, McCaughan BC, Henderson DW, Klebe S (2011b) Validation of tissue microarray technology in malignant pleural mesothelioma. Pathology 43(2): 128-132.

Kao SC, Lee K, Klebe S, Henderson D, McCaughan B, Vardy J, Clarke S, van Zandwijk N (2013) Excision repair cross complementation group 1 and thymidylate synthase expression in patients with mesothelioma. Clin Lung Cancer 14(2): 164-171.

Kawata E, Ashihara E, Maekawa T (2011) RNA interference against polo-like kinase-1 in advanced non-small cell lung cancers. J Clin Bioinforma 1(1): 6.

Kim SJ, Nakayama S, Miyoshi Y, Taguchi T, Tamaki Y, Matsushima T, Torikoshi Y, Tanaka S, Yoshida T, Ishihara H, Noguchi S (2008) Determination of the specific activity of CDK1 and CDK2 as a novel prognostic indicator for early breast cancer. Ann Oncol 19(1): 68-72.

King SI, Purdie CA, Bray SE, Quinlan PR, Jordan LB, Thompson AM, Meek DW (2012) Immunohistochemical detection of Polo-like kinase-1 (PLK1) in primary breast cancer is associated with TP53 mutation and poor clinical outcom. Breast Cancer Res 14(2): R40.

Kneisel L, Strebhardt K, Bernd A, Wolter M, Binder A, Kaufmann R (2002) Expression of polo-like kinase (PLK1) in thin melanomas: a novel marker of metastatic disease. J Cutan Pathol 29(6): 354-358.

Lane HA, Nigg EA (1996) Antibody microinjection reveals an essential role for human polo-like kinase 1 (Plk1) in the functional maturation of mitotic centrosomes. J Cell Biol 135(6 Pt 2): 1701-1713.

Lanphear BP, Buncher CR (1992) Latent period for malignant mesothelioma of occupational origin. J Occup Med 34(7): 718-721.

Le Tourneau C, Faivre S, Laurence V, Delbaldo C, Vera K, Girre V, Chiao J, Armour S, Frame S, Green SR, Gianella-Borradori A, Dieras V, Raymond E (2010) Phase I evaluation of seliciclib (R-roscovitine), a novel oral cyclin-dependent kinase inhibitor, in patients with advanced malignancies. Eur J Cancer 46(18): 3243-3250.

Li L, Yang L, Scudiero DA, Miller SA, Yu ZX, Stukenberg PT, Shoemaker RH, Kotin RM (2007) Development of recombinant adeno-associated virus vectors carrying small interfering RNA (shHec1)-mediated depletion of kinetochore Hec1 protein in tumor cells. Gene Ther 14(10): 814-827.

Linton A, Vardy J, Clarke S, van Zandwijk N (2012) The ticking time-bomb of asbestos: its insidious role in the development of malignant mesothelioma. Crit Rev Oncol Hematol 84(2): 200-212.

Livak KJ, Schmittgen TD (2001) Analysis of relative gene expression data using real-time quantitative PCR and the 2(-Delta Delta C(T)) Method. Methods 25(4): 402-408.

Lopez-Rios F, Chuai S, Flores R, Shimizu S, Ohno T, Wakahara K, Illei PB, Hussain S, Krug L, Zakowski MF, Rusch V, Olshen AB, Ladanyi M (2006) Global gene expression profiling of pleural mesotheliomas: overexpression of aurora kinases and P16/CDKN2A deletion as prognostic factors and critical evaluation of microarray-based prognostic prediction. Cancer Res 66(6): 2970-2979.

Meyer A, Merkel S, Bruckl W, Schellerer V, Schildberg C, Campean V, Hohenberger W, Croner RS (2009) Cdc2 as prognostic marker in stage UICC II colon carcinomas. Eur J Cancer 45(8): 1466-1473.

Mgbonyebi OP, Russo J, Russo IH (1998) Roscovitine inhibits the proliferative activity of immortal and neoplastic human breast epithelial cells. Anticancer Res 18(2A): 751-755.

Nigg EA (1998) Polo-like kinases: positive regulators of cell division from start to finish. Curr Opin Cell Biol 10(6): 776-783.

Pandha HS, Protheroe A, Wylie J, Parker C, Chambers J, Bell S, Munzert G (2008) An open label phase II trial of BI 2536, a novel Plk1 inhibitor, in patients with metastatic hormone refractory prostate cancer (HRPC). J Clin Oncol 26(15S): 14547.

Pass HI, Liu Z, Wali A, Bueno R, Land S, Lott D, Siddiq F, Lonardo F, Carbone M, Draghici S (2004) Gene expression profiles predict survival and progression of pleural mesothelioma. Clin Cancer Res 10(3): 849-859. 
Relan V, Morrison L, Parsonson K, Clarke BE, Duhig EE, Windsor MN, Matar KS, Naidoo R, Passmore L, McCaul E, Courtney D, Yang IA, Fong KM, Bowman RV (2013) Phenotypes and karyotypes of human malignant mesothelioma cell lines. PLoS One 8(3): e58132.

Roe OD, Anderssen E, Sandeck H, Christensen T, Larsson E, Lundgren S (2010) Malignant pleural mesothelioma: genome-wide expression patterns reflecting general resistance mechanisms and a proposal of novel targets. Lung Cancer 67(1): 57-68.

Romagnoli S, Fasoli E, Vaira V, Falleni M, Pellegrini C, Catania A, Roncalli M, Marchetti A, Santambrogio L, Coggi G, Bosari S (2009) Identification of potential therapeutic targets in malignant mesothelioma using cell-cycle gene expression analysis. Am J Pathol 174(3): 762-770.

Sebastian M, Reck M, Waller CF, Kortsik C, Frickhofen N, Schuler M, Fritsch H, Gaschler-Markefski B, Hanft G, Munzert G, von Pawel J (2010) The efficacy and safety of BI 2536, a novel Plk-1 inhibitor, in patients with stage IIIB/IV non-small cell lung cancer who had relapsed after, or failed, chemotherapy: results from an open-label, randomized phase II clinical trial. J Thorac Oncol 5(7): 1060-1067.

Singhal S, Wiewrodt R, Malden LD, Amin KM, Matzie K, Friedberg J, Kucharczuk JC, Litzky LA, Johnson SW, Kaiser LR, Albelda SM (2003) Gene expression profiling of malignant mesothelioma. Clin Cancer Res 9(8): 3080-3097.

Spankuch B, Heim S, Kurunci-Csacsko E, Lindenau C, Yuan J, Kaufmann M, Strebhardt K (2006) Down-regulation of Polo-like kinase 1 elevates drug sensitivity of breast cancer cells in vitro and in vivo. Cancer Res 66(11): 5836-5846.
Tyagi S, Bhui K, Singh R, Singh M, Raisuddin S, Shukla Y (2010) Polo-like kinase1 (Plk1) knockdown enhances cisplatin chemosensitivity via up-regulation of p73alpha in p53 mutant human epidermoid squamous carcinoma cells. Biochem Pharmacol 80(9): 1326-1334.

Vogelzang NJ, Rusthoven JJ, Symanowski J, Denham C, Kaukel E, Ruffie P, Gatzemeier U, Boyer M, Emri S, Manegold C, Niyikiza C, Paoletti P (2003) Phase III study of pemetrexed in combination with cisplatin versus cisplatin alone in patients with malignant pleural mesothelioma. J Clin Oncol 21(14): 2636-2644.

Wolf G, Elez R, Doermer A, Holtrich U, Ackermann H, Stutte HJ, Altmannsberger HM, Rubsamen-Waigmann H, Strebhardt K (1997) Prognostic significance of polo-like kinase (PLK) expression in non-small cell lung cancer. Oncogene 14(5): 543-549.

Wong RP, Aguissa-Toure AH, Wani AA, Khosravi S, Martinka M, Li G (2012) Elevated expression of Rad18 regulates melanoma cell proliferation. Pigment Cell Melanoma Res 25(2): 213-218.

Wu G, Qiu XL, Zhou L, Zhu J, Chamberlin R, Lau J, Chen PL, Lee WH (2008) Small molecule targeting the Hec1/Nek2 mitotic pathway suppresses tumor cell growth in culture and in animal. Cancer Res 68(20): 8393-8399.

This work is published under the standard license to publish agreement. After 12 months the work will become freely available and the license terms will switch to a Creative Commons AttributionNonCommercial-Share Alike 3.0 Unported License.

Supplementary Information accompanies this paper on British Journal of Cancer website (http://www.nature.com/bjc) 